\title{
INTERNATIONAL DEVELOPMENT AND BILATERAL AID TO KENYA IN THE 1990s
}

\author{
John R. Campbell \\ Department of Sociology and Anthropology, School of Oriental and African Studies, \\ University of London, Thornhaugh St., Russell Square, London WC1H 0XG, UK. \\ Email: jc58@soas.ac.uk
}

KEY WORDS: Bilateral donors; Development policy; Kenya; Non-governmental organizations (NGOs)

This paper seeks to analyze a decade of international development in Kenya through the lens of a multi-sited and multi-level ethnographic analysis. It demonstrates the inherently messy and political nature of development as well as the need to analyze the social and cultural contexts in which policies are debated, negotiated, and implemented. An anthropological approach provides insight into the complexity of development policy and the unpredictability of development outcomes which are obscured by research that relies on policy texts and/or eschews empirical fieldwork.

OVER THE PAST SEVERAL DECADES there has been a massive outpouring of research on non-governmental organizations (NGOs) in international development. Initial work in the early 1980 s tended to accept claims regarding their efficacy in alleviating poverty and/or hunger in the Third World. ${ }^{1}$ In the late 1980 s empirical research began to document the diversity of organizational types found among NGOs, indicating considerable variability in their forms, functions, and activities. In East Africa, for instance, immense operational and philosophical differences are found between local-level, national, and international NGOs. ${ }^{2}$ Research also began to look at the constraints faced by NGOs in their day-to-day operations, which in turn led to an appreciation of the wider policy environments in which they operated and an attempt to identify an "enabling" environment conducive for NGO operations. ${ }^{3}$ Finally, research found that a distinction between "the state" and NGOs obscured key overlaps. For example, a nation-state may create and fund NGOs, and NGOs often recruit government personnel and rely on government funding. An understanding of this inter-relationship allows a much clearer grasp of the emergence of clearly observable tensions and conflicts between NGOs and the state, particularly in the context of the rapid growth of NGOs (Bratton 1989).

Somewhat curiously, while researchers have debated the concept and the possibility of "participation" in development, ${ }^{4}$ a term that lies at the heart of NGO claims, ethnographers have not examined the participatory claims of NGOs or of NGO projects (Botchway 2001; Mosse 2005a; Porter, Allen, and Thompson 1991). Even so, it is clear that the meaning and possibility of "participation" varies greatly over time, by place, and between countries and projects.

In retrospect it would appear that a great deal of our knowledge about the

Journal of Anthropological Research, vol. 64, 2008

Copyright $(\mathcal{C}$ by The University of New Mexico 
process and politics of international development, and especially about the work of different development institutions, is of variable quality owing to the fact that many of those who write about development adopt a normative approach. For instance, many writers fail to critically examine the reality behind NGO rhetoric. Thus, in the 1980s, writers championed NGOs, which were, it was argued, better positioned to "do" development than the state. Subsequently, many now argue that NGOs are "democratic actors" involved in pursuing democratic change and widening citizen participation (Mercer 2002). In effect, such claims reflect an uncritical acceptance of representations by development organizations that development is "a set of self-evident universals, a common sense abstracted and autonomous from actual relations, having a logic of its own (that of market relations) and subject to policy levers acting on behavior through institutional rules and incentives" (Mosse 2005b:27). In short, they assume that the system of aid is rational and coherent and that development institutions such as NGOs can be understood as rational actors.

A second problem confronting research on international development arises when findings from research on a particular NGO and/or project are generalized to other contexts and/or organizations. A great deal of development research is based on data collected in brief visits to a small number of organizations that operate in unique locales. A further problem arises from research that eschews empirical fieldwork, preferring analysis of policy documents (e.g., Abrahamsen 1997; Escobar and Alvarez 1995; Ferguson 1990). Research on development encounters significant problems given the need to grapple with the issue of scale, the problem of grasping activities at different sites, and the difficulty of analyzing myriad organizations whose professed intentions are often at odds with organizational outcomes.

Recently anthropologists have begun to focus on aspects of fluidity, resource flows, and transnational links to analyze NGO projects (Mosse 2005a). Indeed, development policy and practice are ideal subjects for pursuing multi-sited ethnography in an attempt to understand policy implementation, capture "people's understandings of shifting cultural milieus," and analyze the interconnections among beneficiaries, grassroots NGOs, intermediary NGOs, and donors (Markowitz 2001; Mosse 2005a).

In this paper I pursue a multi-sited ethnography to analyze an area of development policy and practice that is poorly understood and little researched, namely the political field constituted by the relations among foreign aid agencies, a host government, and a diverse range of NGOs. In particular I examine the way in which development policy in Kenya unfolded in the 1990s (Figure 1). This paper has three objectives. First I seek to differentiate between the rhetoric and reality exhibited by NGO projects/programs during the 1990s. Second I examine the political relations among NGOs, the Kenyan government, and foreign aid agencies. Finally I reinterpret the donor development discourse-in other words, development as a strategic partnership to reduce poverty-that obscures the highly charged political relationship that exists with the Kenyan government.

I need first to acknowledge my position in the web of relations this paper describes. Having already worked for nearly 6 years in East Africa (including 


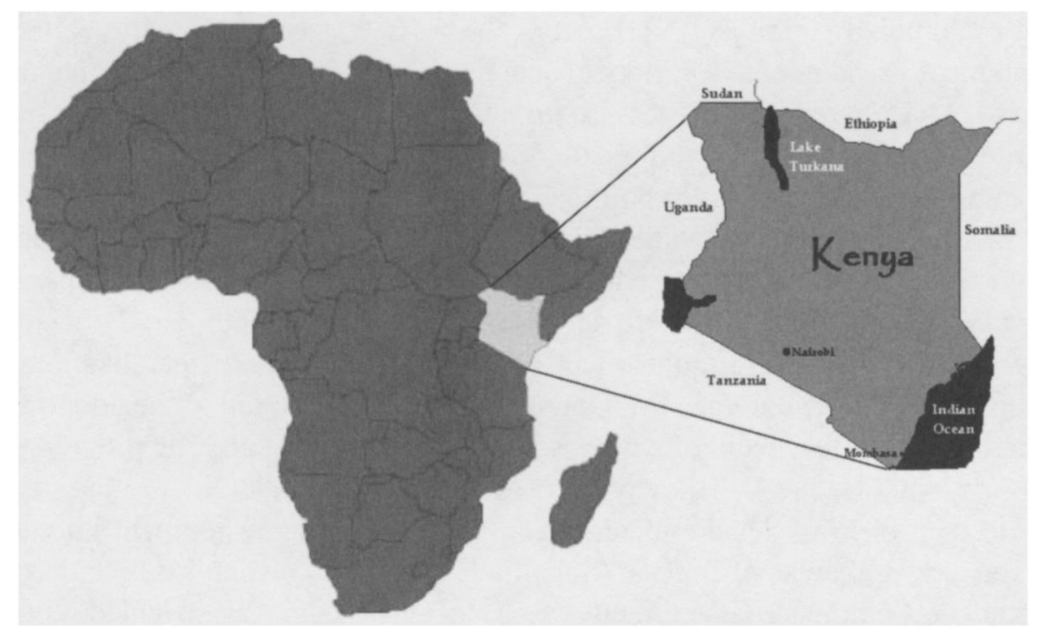

$1 \frac{1}{2}$ years setting up an NGO), I first went to Kenya in 1994 as a development consultant hired by the UK Department for International Development (UK DFID). I joined a large World Bank Poverty Assessment of Kenya, and my brief was to examine the perspectives and approaches taken by NGOs to reduce poverty (Campbell 1994). I returned in 1998, again as a DFID consultant, to assess the potential contribution of Kenyan civil society organizations to reduce poverty; this gave me an opportunity to assess the NGO sector, visit projects, and interview bilateral aid agencies. I returned in 1999 to evaluate one of DFID's flagship NGO projects, whose principal objective was to create social capital in coastal Kenya. Later in 1999 I returned to take part in an evaluation of DFID's entire funding scheme for NGOs, known as the Direct Funding Initiative. I draw on these various engagements, based as they are on a mix of participant observation, interviews, documentary analysis, project visits, and project evaluation, to show how the NGO field is structured by various tensions, notably around funding. It should be clear that none of the information cited here was provided in confidence; although DFID initially embargoed my reports, I was subsequently given permission to publish.

The next section outlines the policy and political environment in Kenya during the 1990s, including the shifting focus of bilateral support for NGOs. The next section assesses the poverty-related work of NGOs in 1994, and the following section assesses development in the late 1990s, which ended in a failed attempt by foreign aid agencies to enroll key officials in a new development "partnership" called the National Poverty Eradication Plan. The paper concludes by revisiting the contribution of ethnographic research in producing a more informed and empirically rich account of the politically messy character of development policy and practice.

\section{THE POLICY AND POLITICAL CONTEXT IN KENYA}

The policy environment was overshadowed by the corrupt administration of President Arap Moi, who came to power in 1978 at the head of the ruling Kenya 
African National Union (KANU) party. The party was riven by factions linking members of parliament to a variety of social and ethnic groups. The internal crisis within KANU, together with pressure from Kenya's donors, resulted in multi-party elections in 1992 and 1997. Political corruption was the concern of international donors who sought to monitor political developments and to exercise a degree of control over the regime by withholding/withdrawing aid and by funding NGOs.

In 1981 the government adopted neoliberal economic policies linked to decentralization (through the District Focus for Rural Development, DFRD) and the adoption of structural adjustment programs (e.g., market liberalization and divestiture of public enterprises). Donor pressure also resulted in the adoption of a clearer poverty focus and of anticorruption measures, though little progress was realized. Notably, the DFRD gave rise to a "dual system" allowing the central state to control local development, which stymied local development initiatives and starved rural areas of finance (Schall 1998). Donors responded by bypassing the state and funding NGOs directly; assistance to NGOs was provided with the intention of offsetting criticism about structural adjustment and in line with donor efforts to reform the state and the public sector (Kanyinga 1993).

By the mid-1990s the political situation became tense as Moi targeted individuals and organizations that opposed him, subjecting them to growing harassment, intimidation, and violence. For example, the offices of NGOs involved in rights-based campaigning were burned, and staff were arrested and intimidated. At about the same time, Moi engineered violence in areas dominated by his political opponents (including "ethnic clashes" in the Rift Valley area; Southall 1999). Moi also evicted tens of thousands of "squatters" from government-owned land in order to reward his supporters. ${ }^{5}$

Professed attempts by donors to curb the excesses of the Moi regime were, in the early half of the decade, largely restricted to reducing bilateral funding to the Kenya government. They cut existing funding in the (vain) hope of putting pressure on the state. These efforts coincided with a broader shift in international development policy, specifically the adoption of a commitment to "governance" and "human rights" (van Gastel and Nuijten 2006). However, such policies did not significantly alter the deeply entrenched bureaucratic modalities that bilateral agencies used to disburse aid. For instance, the conservative focus of British aid was reinforced by the decentralization of aid decisions to the regional office in Nairobi (at the time it was the headquarters for Kenya, Tanzania, and Uganda). ${ }^{6}$ British aid was characterized by bilateral support to government ministries-little support was given to NGOs unless they were subcontracted to a government project.

During the 1990s many bilateral agencies were reorganized (owing to rising public debt in Canada, changing Congressional priorities in the US, or policy reviews carried out by new governments, such as in the UK and The Netherlands). ${ }^{7}$ Furthermore, the level of foreign aid declined substantially (the major exceptions being Denmark, The Netherlands, and Japan) at a time when agencies were embracing wider policy objectives (i.e., poverty reduction and promoting democracy and good governance). There is little evidence to support the effectiveness of bilateral aid at this time. ${ }^{8}$ Indeed the Organization for Economic 
Cooperation and Development notes that growing policy objectives, including a greater emphasis on integrating foreign policy and overseas aid, was not coupled with a genuine dialogue with recipient governments. This conclusion is amply supported by events in Kenya.

There are four reasons why bilateral agencies provided limited funding to NGOs in Kenya. First, bilateral aid programs are top-heavy bureaucracies whose operational procedures favor the dispersal of large amounts of money; their procedures effectively exclude small NGOs who do not have the administrative capacity to complete lengthy application forms or comply with numerous reporting requirements. Indeed, most bilateral agencies fund NGOs from their own country or organizations that they "create." Second, bilateral agencies possess a myopic and limited understanding of Kenya and its development needs; frequently, political considerations take precedence over the provision of development assistance. ${ }^{10}$ Third, decision-making in bilateral agencies is complicated by internal disagreements and debates. For example, in the British aid program tensions developed between its Social Development and Governance divisions, which undermined the development of a coherent NGO program, and there were managerial concerns that NGO funding would "fragment" the bilateral aid program. Donor funding generally, and especially with regard to the NGO sector, sought to achieve a degree of leverage over the Kenyan state, but such an objective was undermined by limited cooperation until the late $1990 \mathrm{~s}^{11}$

Regardless of the strategies pursued by bilateral agencies, the Kenyan government's poor implementation of neoliberal policies and anticorruption reforms was a constant concern to donors. In early 1994 the World Bank sent a mission to Kenya to monitor the government's progress. As a member of this mission I was tasked with understanding the "institutional factors" involved in poverty alleviation and service delivery from the perspective of NGOs.

\section{POVERTY AND NGO PROGRAMS IN 1994}

The ideology of self-help and "participation" has a long history in Kenya. In the postcolonial period, harambee (a "self-help" program initiated in 1963) linked thousands of communities directly to the state, forming a vehicle for the mobilization of support for local development and a means for KANU to dispense patronage (Holmquist 1984; Kanyinga 1993). Development (maendeleo) has been the responsibility of the Office of the President since independence; however, under President Moi very little funding was given to local communities (Udvardy 1990). By the late 1980s the absence of government funding for local development together with the impact of structural adjustment and liberalization defined the context for the adoption of "participation"-in which local people assume responsiblity for developing their community - as the modality for development. In this context the hope was that NGOs would serve as conduits linking communities to the state and to donors

Donors had their own reasons for promoting participation; for example, it was seen as way of bypassing a "corrupt" state. Thus "shifts in donor policy and practice have, equally, brought participation into the mainstream, both through 
an emphasis on the use of participatory methods within the context of the project cycle and commitment to civil society participation in determining development directions" (Cornwall, Musyoki, and Pratt 2001:1). Critically, rather than opening up a dialogue with local people as a step in defining and meeting local needs, donors have instead used the mantra of "participation" to push their agendas. The net effect has been to shift the burden of development costs onto local people and away from the state, and to limit participation to instrumental forms of "consultation" (i.e., one-off meetings to generate a plan and/or review a project).

The involvement of "foreign" NGOs in development began during the colonial period with the Christian churches. By the late 1970s there were about 120 foreign and local NGOs. As of 1988 Kanyinga had identified 135 foreign NGOs (most of which had operational programs and provided limited assistance to local organizations) and 149 local NGOs (1993:64). It was estimated that these organizations had a combined annual budget of US\$150-200 million, which represented $30-40 \%$ of development expenditure (Table 1; Kanyinga 1993:67). In 1991, and as a consequence of the money coming into this sector, the Kenyan government introduced greater regulatory control. In response the National Council of NGOs was formed as a means of negotiating with the government. By 1994 about 400 NGOs were registered with the government, while another 100 organizations waited to be registered. By 1998 the number of registered NGOs had risen to 1,028 (Table 2).

Table 1 necessarily simplifies the diversity that exists across the sector and with respect to individual NGOs; individual organizations tend to pursue a range of projects as and when they obtain funding. Little accurate information exists about the operations of NGOs. International NGOs (INGOs), though small in number, dominate work in development, relief, and "technical" (e.g., water, appropriate technology) areas. In 1994 INGOs were primarily concerned with running their own programs; a few of them were funding a small number of local NGO "partners." In 1994 this relationship was mirrored in the work of existing NGO

TABLE 1

The NGO sector in Kenya in 1988

\begin{tabular}{lr}
\hline Sector & $\%$ \\
\hline Relief and welfare & 24 \\
Development & 32 \\
Technical services & 25 \\
Environment & 5 \\
Other & 14 \\
\hline
\end{tabular}

Source: Kanyinga 1993:67

TABLE 2

The NGO sector in 1998 in Kenya

\begin{tabular}{lr}
\hline Sector & $\%$ \\
\hline Natural resources & 14 \\
Education & 6 \\
Youth/family & 4 \\
Water & 3 \\
Social services & 13 \\
Livelihoods & 11 \\
Population and health & 14 \\
Pastoralism & 6 \\
Microfinance & 4 \\
Urban & 3 \\
Culture/religion & 8 \\
Human rights & 8 \\
Emergency & 6 \\
\hline
\end{tabular}

Data provided by NGO Council 
organizations, each of which pursued a specific issue: $(a)$ the NGO Council sought to address the effect of government policies on NGOs (notably concerns about registration and accountability but also the problems created by ethnic clashes); (b) the INGO Coordinating Committee monitored economic issues (e.g., the effect of the currency devaluation and Value Added Tax on operational budgets); and $(c)$ other fora-the Pastoralist Steering Committee, the Shelter Forum, etc.exchanged information and/or lobbied on specific issues.

NGOs varied greatly in their understanding of and approach to poverty reduction. Given space limitations, a few examples will have to suffice. The "technical" NGOs - those concerned with appropriate technology and enterprise creation-subscribed to a market-driven focus wherein individuals who possessed sufficient capital could apply for support and credit to expand their existing enterprises. These organizations clearly did not see it as their task to assist the poor; they rationalized their programs in terms of creating jobs in existing small enterprises. ${ }^{12}$ Thus, as the director of one organization stated, "The poorest are those who have no commercial background, have failed to earn a living, and who are primarily interested in finding secure employment. Such people are not [our] target group." 13

A somewhat different view was articulated by a local NGO which began as a relief organization and which used food aid to improve primary school attendance and child nutrition. A project official from Kenya Freedom From Hunger linked the international metric of weight for height to "community" criteria to define the vulnerable as families "with no father (i.e., headed by a widow), large household size, few or no cattle, and families who withdrew from communal activities because they could not afford to participate."

This view was expressed by educated, urban-based project staff and was shaped partly by funding constraints. Their implicit paternalism is shaped partly by the project's reliance on food aid and (possibly self-selected) community health workers whose view of poverty was defined solely in terms of whether a household had "malnourished" children. Health workers at a project in Embu told me that poor households were those that contained malnourished children; had few possessions and clothes; had poorly built homes (poor people slept on the dirt floor of their house); and whose children were unable to attend school and ate inadequate food. On this basis they estimated that between $25 \%$ and $33 \%$ of households were "poor." However, my discussion with health workers revealed that the principal cause of poverty arose from the pressure that population growth placed on existing land, and the fact that households allowed all their children (sons and daughters) to inherit land. In short, the fragmentation of land holdings was resulting in households having access to significantly less productive land. Poverty caused by structural factors such as population growth will not, however, be reduced by food aid.

The work of the National Christian Council of Kenya (NCCK), Kenya's largest NGO, provides an interesting contrast. According to the director of NCCK's urban programs, the poor are those who are unable to meet their basic health and food needs. However, as with many organizations, assistance is not provided directly to individuals but rather to selected households and the 
community via a small-group-loan scheme, a model pioneered in South Asia. The Women in Stress project in a Nairobi slum represented a different vision in which poor, uneducated, and unmarried women responsible for young children were provided counseling (and perhaps limited credit). The emphasis in this project was to stabilize the family situation of the women so they could earn income to support their families. However, the complex problems confronting poor urban women were not amenable to easy solutions, and the lack of tangible outcomes failed to attract donor funding. Staff articulated a distinctive view of the problem: poor people, they said, have no hope or vision for the future. It was first necessary to restore self-belief and a hope for a better future by helping individuals to help themselves (a process in which external aid could only assist by funding more and better counseling). NCCK's emphasis was to provide material assistance to communities/individuals via group loans and to counsel destitute women.

A contrasting view was articulated by the director of Oxfam-UK, ${ }^{14}$ who recognized that Oxfam had serious problems in reaching the poor because of its history (it began by supporting the Catholic missions) and because it did not have a strategy to identify or work with the poorest. In 1994 Oxfam sought to overcome these problems by using Participatory Rural Appraisal (PRA; Chambers 1994) to transform its work with pastoralists from emergency relief into a development project (see below). This contrasts sharply with many NGOs and aid programs, which find it easier to work with locally organized "self-help" groups or with individuals who are believed to be especially "vulnerable." The problem of assisting self-help groups is that they are the culmination of a process of selfselection in which relatively better off individuals come to dominate and define project activities (often at the expense of the poorest or in terms of gender equity; Chaiken 1990; Mwaniki 1986). Similarly, programs that assist "vulnerable" people tend to misperceive the nature of vulnerability and, at best, only help some individuals meet their immediate survival needs while failing to address the root cause of poverty (Udvardy 1998).

Despite such diverse approaches, there was little evidence in 1994 that NGOs were able to identify, much less alleviate, rural or urban poverty. Indeed, they were just beginning to move away from projects focused on service delivery, and the elimination of poverty, as a specific issue, was yet to surface. NGOs were greatly concerned with the poor policy environment and with structural adjustment, both of which were undermining the education and health sector; most NGOs experienced difficulty in securing donor funding partly in light of the rapid growth of the sector and because donors "cherry-picked" specific NGOs or particular NGO projects. To make matters worse, INGOs pursued a self-interested strategy in selecting a local NGO as their "partner." Tellingly, the deep-seated hostility most NGOs felt toward the government was extended to the World Bank. $^{15}$

\section{DEVELOPMENT IN THE LATE 1990s}

Between 1994 and 1999 the political and policy environment in Kenya deteriorated. Structural adjustment led to a further erosion of basic services and to rising 
poverty: the number of poor increased from an estimated 11.5 million in 1995 to 12.5 million in 1997 , which meant that $53 \%$ of rural and $49 \%$ of urban households were living below the poverty line (United Nations Development Program [UNDP] 2003:4). The government had also failed to implement policy reforms, including the DFRD, which meant that local development was nonexistent.

Rising corruption and continuing political problems led donors to establish a number of informal fora to exchange information and monitor the political situation. They included UNDP-coordinated meetings which examined possible ways of "leveraging issues with the Government of Kenya" (e.g., to push the poverty agenda), ${ }^{16}$ the Like-Minded Donors Group, various World Bankconvened Sector Discussion Groups, and the Economic Governance Group or EGG. This latter forum, chaired by The Netherlands and attended by bilateral and multilateral agencies, monitored corruption and the government's implementation of structural adjustment policies (without which donors threatened to withdraw their funding). By mid-1998 the EGG was also attempting to agree to a set of standards for funding NGOs, ${ }^{17}$ though progress toward this objective was slow because bilateral agencies "lacked a strategic view of the sector and of rights and democracy issues"18 and/or because aid programs were defined by their respective embassies (i.e., by foreign-policy considerations).

By the late 1990s the government of Kenya had relaxed controls over the registration of NGOs, which led to a proliferation of small, poorly organized and funded, and woefully ambitious organizations. The areas that saw the most rapid growth were related to work with pastoralists, health (notably HIV/AIDS), gender, and natural resources.

The vast majority of registered NGOs were based in Nairobi and/or central Kenya. This geographic clustering is underlined by the fact that only 60 to 100 organizations, many of which were Christian churches, operated in the 15 poorest rural districts (Table 3 ). In short, very few NGOs were geographically positioned to address rural poverty directly. Interestingly, NGO expansion in the 1990s does not appear to have resulted from access to international funding (though the expectation of funding may have been a factor in the establishment of such organizations; Kanyinga 1993).

By the late 1990s INGOs recognized that their "partners"-small NGOs and community-based groups-lacked the ability to undertake their stated objectives, which led to the development of "capacity-building"19

TABLE 3

NGOs operating in the 15 poorest districts in Kenya, 1998

\begin{tabular}{lc}
\hline District & $\begin{array}{c}\text { Number } \\
\text { of NGOs }\end{array}$ \\
\hline Marsabit & 4 \\
Samburu & 4 \\
Isiolo & 3 \\
Makueni & 4 \\
Turkana & 8 \\
Tana River & 3 \\
Machakos & 8 \\
Mandera & 2 \\
Kilifi & 3 \\
Embu & 3 \\
Kericho & 3 \\
Busia & 7 \\
Bungoma & 6 \\
Vihiga & 6 \\
Nyamira & 2 \\
Wajir & 3 \\
\hline
\end{tabular}

Data provided by NGO Council 
programs aimed at providing organizational development training to local NGOs and community groups. While bilateral agencies bemoaned the seemingly endless drain on their resources represented by such programs, they nevertheless funded capacity-building as one activity by which to attain their wider strategic interests (see Gould 2006). Thus the stated aim of British support for NGO capacitybuilding was "strengthening structures with a focus on poverty" and "shifting responsibility [for development work] to community organisations" (Thom 1997:27). British assistance focused on assisting NGOs to develop the "capacity to identify, support, administer and monitor programmes" capable of reducing poverty rather than merely addressing the symptoms of poverty (Holloway 1998:26).

In the mid-1990s DFID financed the British NGO Action-Aid Kenya(AAK) to create a capacity-building program for local NGOs. The principal objective of this program from AAK's point of view was to move beyond its "inherent weakness" as a "foreign agency" to expand its mandate for advocacy by increasing the spread of NGOs and creating a network capable of influencing national policy (ActionAid Kenya 1993:47). British funding provided the means to realize this ambition while at the same time it allowed DFID to define "standards of good practice" in the sector (i.e., by instituting participatory capacity assessments, financial management systems, improving NGO governance and program planning; Muir and Riak 1998). The first phase of the project provided assistance to 56 NGOs/ community-based organizations (CBOs). Although subsequent evaluation showed little evidence that the assisted organizations had reduced poverty, there was considerable evidence that the program had created a demand for "empowerment" (i.e., further assistance). By funding capacity building, DFID created a dendritic network of influence involving itself, an intermediary (British) INGO, and local NGOs and CBOs. ${ }^{20}$ Though local organizations were poorly positioned to deliver development assistance, their real value lay in communicating and elaborating the tenets of neoliberal economic discourse and political reform to ordinary citizens.

Significantly, a small number of left-leaning advocacy and social mobilization NGOs developed in the mid- to late 1990s, including some secondgeneration NGOs that grew out of community networks (as distinct from those that grew out of NGO offices; e.g., Kituo cha Sheria). Although development NGOs had little access to donor funding, bilateral agencies did provide support for "rights-based" activities and for short-term projects focused on the 1997 national elections. ${ }^{21}$ The US supported 15 rights-based organizations, ${ }^{22}$ while Scandinavian countries supported a smaller number of organizations with whom they had a long-term relationship, and the German trade union Frederick Ebert Stiftung provided limited funding. Britain played a marginal role because its funding criteria were too conservative and its bureaucracy too inflexible to meet the needs of "rights-based" NGOs. In any event, the length of time required to strengthen the organizational capacity of networks and educate community members about their rights meant that these initiatives were unable to absorb significant levels of funding.

As we have seen, though bilateral agencies espoused the need to widen opportunities for citizen "participation," they provided limited support for 
"rights-based work" and focused instead on cyclical forms of support for "civic education" campaigns and election monitoring activities. At the same time, donor support for civic education was relatively new. Many of the programs suffered from the same deficiencies, namely: $(a)$ all were based in Nairobi and run by lawyers; $(b)$ nearly all had very poor linkages to the rural population; $(c)$ they had not given adequate consideration to defining their entry point into communities; $(d)$ they had not developed an adequate strategy for "educating" citizens; and $(f)$ they were unable to assess or uninterested in assessing the effectiveness of their strategies (Frontier Consulting 1998; Maina et al. 1997; Southall 1999).

Moreover, the Danish, British, Swedish, and Dutch bilateral agencies made it a precondition of their funding that a number of organizations should merge for the short-term objective of monitoring the 1997 general election. Although this project was judged to be "generally successful" in deploying 27,000 poll watchers, 840 campaign monitors, and 420 count certifiers, it was unable to ensure "free and fair" elections. Further, the centralized form of planning imposed by the donors undermined future cooperation (Frontier Consulting 1998). In this area, as elsewhere, donors pushed their agenda onto NGOs through a combination of rewriting funding proposals, funding only the aspects of a program that suited their interests, and providing limited support for recurrent costs. Some agencies funded specific individuals to undertake civic education work rather than assessing the sector to identify appropriate organizations. Donors tended to fund the same organization regardless of its performance, which resulted in projects that were narrowly focused on the better-educated, on Christians rather than Muslims, and on the same ethnic groups (Frontier Consulting 1996; Maina et al. 1997).

The volume of donor funding for NGOs and other organizations in the late 1990 s is difficult to assess. Table 4 summarizes data provided by the principal funding agencies for programs that were run and/or funded by their Nairobi offices (it excludes funding administered from abroad). Approximately $£ 7$ million per year was disbursed in Nairobi between 1997 and 1999. The large number of grants obscures two facts: many agencies funded the same NGOs, and four agencies funded NGO activities (meetings, networking, training, computers) but not recurrent costs, programs, or projects. In short, bilateral funding was limited in scope, and it was distributed to a small number of organizations.

Clearer insight into the nature of bilateral funding for NGOs and other organizations comes from the 1999 review of DFID's Direct Funding Initiative (DFI), one of six mechanisms through which DFID funds NGOs. The DFI began in 1994 with the objective of enhancing the "poverty focus" of British aid and was justified on the grounds of efficiency and the need to learn lessons from NGOs. However, even at the height of DFI funding in 1999 , only $9 \%$ ( $£ 13$ million) of British bilateral aid was spent on fifteen NGOs; the remainder went to international (especially British) NGOs. The findings of the 1999 review illustrate the problems inherent in bilateral support for NGOs. The consultants who performed the review were asked to assess the appropriateness and coherence of the DFI within Britain's overall aid program. Key questions were raised as to whether the funded projects achieved their stated objectives and whether the DFI provided "value for money." 
TABLE 4

Bilateral funding to Kenyan NGOs/Civil Society Organizations in 1998

\begin{tabular}{|c|c|c|c|}
\hline Organization & $\begin{array}{l}\text { Applications } \\
\text { per year }\end{array}$ & $\begin{array}{l}\text { Current } \\
\text { Grants }\end{array}$ & $\begin{array}{l}\text { Program Budget } \\
\text { per year }\end{array}$ \\
\hline DFID - Direct Funding Initiative & 60 & 15 & $£ 1$ million \\
\hline DFID - Governance & $?$ & 17 & $£ 1.5$ million \\
\hline $\begin{array}{l}\text { British Council - Post Beijing Portfolio } \\
\text { (funding from DFID/British Foreign and } \\
\text { Commonwealth Office) }\end{array}$ & 150 & 11 & $£ 300,000+$ \\
\hline Swedish International Development Agency & - & 15 & $£ 365,000$ \\
\hline Royal Netherlands Embassy & - & $7-10$ & $\begin{array}{l}\text { Guilder } 1.5-3 \\
\text { million }\end{array}$ \\
\hline DANIDA & 111 & 35 & unknown \\
\hline $\begin{array}{l}\text { USAID - Democracy and Governance } \\
\text { theme }\end{array}$ & 200 & 15 & $\begin{array}{l}\$ 2.1-2.5 \text { million } \\
\text { over } 3 \text { yrs }\end{array}$ \\
\hline Ford Foundation - Human rights and media & $\begin{array}{c}\text { no } \\
\text { information }\end{array}$ & $\begin{array}{c}\text { no } \\
\text { information }\end{array}$ & $\$ 2$ million \\
\hline $\begin{array}{l}\text { Canadian International Development } \\
\text { Agency }\end{array}$ & $5+$ & 3 & $\$ 200,000$ \\
\hline Total & $526+$ & $121+$ & $£ 7$ million \\
\hline
\end{tabular}

Sources: various embassies in Nairobi

The team was restricted to reviewing existing documentation, interviewing grant holders and aid officials, and holding a workshop with NGO "partners" to discuss and assess the program. The review was not participatory because the key issues to be evaluated - whether sustainable improvements had been achieved, what lessons had been learned, and whether local capacity had been created and was sustainable - were defined by DFID. Furthermore the team found that the poor quality of project documentation restricted the conclusions it could reach.

The program was supposed to enhance DFID's ability to alleviate poverty; it was not expected to develop as a discrete project but rather to act as "a funding and management mechanism available to all sectors in DFID Kenya." Prior to the establishment of the program DFID had only occasionally contracted with NGOs to deliver specified inputs for government projects. Indeed, DFID had little knowledge of participatory methods and had not embraced "participation" as a means of providing development assistance.

The review found that at least half of funding for the program had been disbursed to British INGOs (more, if former British organizations are included) and that the projects were unevenly distributed among different DFID divisions. Projects were adjudged to have largely achieved their purposes, but crucially, "it was not possible ... to assess the contribution of projects to poverty reduction" (Scotland, Fleming, and Campbell 1999:14). Furthermore, all but one project 
(see below) appeared to have assisted the poor, to have provided key lessons for development, and to have developed the capacity of local partners. It should be noted that poverty reduction was not necessarily a stated objective of project funding, and in many cases this objective was inferred. Given these parameters it is instructive to look at three projects reviewed by the team.

The project that was judged to have best met its defined purpose was OxfamWajir, a development project that evolved out of a long relationship with local pastoralists dating back to 1984 when Oxfam first provided emergency assistance to them. The development project began in 1994 with the stated aim of reducing poverty and vulnerability by improving self-reliance over a period of nine years. The project is well documented and was the only one for which an economic impact assessment was carried out. The assessment indicated that key components had been successfully implemented and that the project had brought important economic benefits, including a significant reduction in the vulnerability of local communities to drought (Oxfam 1996; Odhiambo, Holden, and Ackello-Ogutu 1998). Oxfam created pastoral development associations which provided a range of vital services to local communities, including wholesaling veterinary supplies and providing a vehicle for collective action (e.g., to manage grazing lands, pool resources, and undertake development projects). However, the evaluation did not consider whether the benefits would survive the withdrawal of government support or the impact of growing regional/ethnic conflict.

The project adjudged least successful was a primary health care project serving pastoralists in Turkana which, since its inception in 1990, had signally failed (Lyons 1998). The key difficulty arose from the organization's reliance on a Western medical model to provide a form of health service through a static health clinic run by staff who lacked the cultural sensitivity to deal with their patients and the competence to manage the project. Initial problems were to have been overcome by enhancing community participation and ownership through cost-sharing and by creating more appropriate forms of communication between staff and clients. However, eighteen years of funding had failed to establish a viable project. Given its history one is left to wonder why the review concluded that its objectives were "likely to be partially achieved" rather than seeing it as an outright failure.

The Kwale Rural Support Program in an area east of Mombasa was heralded as a cutting-edge project whose central objective was to create social capital by reviving village-level institutions which established "productive physical infrastructure" (PPI: a water supply, a road) and provided support for rural livelihoods (e.g., credit, seed and fertilizer packages). The evaluation relied heavily on my review of the project (Campbell and Horton 1998). Owing to a slow start-up, the project was only in its second year of operation. Furthermore, the creation of appropriate and locally sustainable PPIs required a new approach to ensure that women and the rural poor were able to participate.

I organized a Participatory Rural Appraisal (PRA) in one site which indicated the problems facing the project. I asked Kidzuvini village committee members to identify indicators of wealth that reflected the reality of village life; after some discussion they distinguished between rich, middle-income, and poor 
households. I then asked which wealth category they belonged to: two came from rich, eighteen came from middle-income, and nine individuals came from poor households. The economic status of the household had important implications for its ability to participate in and benefit from the project: while all memberhouseholds contributed labor to build the local PPI, half of the poor households could not afford to participate in the savings and credit scheme (and none of the "rich" households chose to save with the scheme). Furthermore, the poor could not afford the time to attend project meetings. In short, not only were the poor underrepresented in the project, the project primarily served the interests of betteroff households. New ways needed to be found to assist the poor to participate in the project.

The review team was asked to comment on the procedures DFID used to assess, fund, and evaluate NGOs and to assess the extent to which lessons had been learned by project administrators and by DFID. Broadly speaking, the team found DFID's procedures to be time-consuming and overly bureaucratic; the procedures created tensions with "partners" by imposing heavy accountability requirements that hindered rather than facilitated partnership (they also blocked small NGOs from accessing support). Just as seriously, DFID proved to be slow at disbursing agreed funds, and despite projects being "owned" by different divisions, disagreements between them-particularly between Social Development and Governance — created tensions that stymied cooperation.

Learning from its NGO partners appeared to be a low priority for DFID. First, lesson-learning was not included as an aspect of project planning. Furthermore, no formal mechanism existed within the program, or indeed within DFID, to monitor and report on projects. Nevertheless project staff could visit other projects and, to a limited extent, access their capacity-building support. Two of the DFI projects employed (seconded) government staff, which established a link to local government offices.

The failure of DFID to learn from its NGO partners represents an important missed opportunity for several reasons. First, the difficult policy context led NGOs to develop innovative ways of responding to the needs of local people and to make the state more responsive to communities. Moreover, the projects shed significant light on broader development problems, ranging from coping with the Kenyan DFRD, transforming an emergency relief project into a successful development project, and learning how to reach poor people. On a broad strategic level, DFID's bureaucratic procedures and its conservative political views prevented it from supporting and learning from cutting-edge, second-generation NGOs like Kituo cha Sharia, which explicitly sought to link access to basic services with the exercise of basic political rights.

If we return to the wider picture we find that by 1998 donors were beginning to collaborate in a joint initiative to enmesh the government in a process of policy reform by enrolling key policymakers - not elected politicians or the public - in a National Poverty Eradication Program located in the Office of the President. Donors elaborated a fiction that the program emerged from "public consultation" with "key stakeholders" when in fact it was written by a DFID consultant with the aim of establishing a charter of citizens' rights, providing better service coverage 
to low-income groups, and elaborating a strategy for "broad-based economic growth" (Republic of Kenya 1998). Indeed, a sixteen-year work plan was drafted which set out a framework for "recruiting national energies" and creating and sustaining "national and local partnerships" to combat poverty (Republic of Kenya 1999). The attempt relied heavily on enlisting a small number of senior officials in the president's office and in two other ministries to join a network of (foreign) policymakers who would generate and implement rational development policies for Kenya. However, the strategy failed completely and the program became the focus of political patronage (Patrick, Els, and Wanyama 2005). The decade ended much as it had begun, with the country run by a corrupt administration which successfully resisted the threats and bribes of donors and demands for local accountability.

\section{CONCLUSION}

Ethnographic fieldwork conducted in a range of development institutions and at a variety of locales and levels illustrates the complex nature of aid relationships and policy implementation. Official rhetoric is often articulated in the form of normative statements which may provide a starting point from which to analyze the development process, but studies that begin and end with policy documents/ statements produce incomplete and simplistic analyses (Abrahamsen 1997; Ferguson 1990; Hauser 1999) of a messy and unpredictable political process.

Rather than recognizing that individual organizations/actors may have their own agendas, recent anthropological work has incorporated the problematic assumption that a significant process of brokerage (Olivier de Sardan 2005) occurs at the development interface between aid organizations. This "translation" "invariably ensures that all actors-perhaps through strategic representationsdefer to dominant or official narratives of agency and history that work to reinstate policy ambitions and to conceal divergent and contradictory logics of practice" (Mosse and Lewis 2006:16). While this observation might be argued to hold for foreign aid agencies (at least in terms of how they represent their work to the public), it is problematic from the point of view of different divisions within an aid agency and with respect to the Kenyan government and various NGOs, some of whom "buy in" to the discourse/policy to access funding while others clearly propagate their own "take" on current policy. Clearly a diversity of positions with regard to donor development discourse is possible, as is demonstrated by the way in which NGOs responded to the British-funded capacity-building program.

Furthermore, the reach of donor influence is limited geographically and by amount (and conditions) of funding. Perhaps a more effective constraint on donor initiatives concerns the small number and size of their NGO clients, not to mention the role played by the state and its officials (e.g., the president) in blocking or otherwise constraining the efforts of foreign aid agencies. For example, neither rights-based nor election-monitoring projects met donor objectives (though such projects did sustain lawyers and other staff); nor were donors successful in reducing corruption or assisting churches or NGOs to become effective democratic actors. In short, it is important not to overemphasize the power of bilateral and multilateral aid agencies whose limitations are demonstrated by their inability to 
cooperate with each other and by internal tensions within their organizations.

Finally, to the extent that research on international development embraces empirically based fieldwork that is multi-sited, multi-vocal, and multi-level, it can examine the contested nature of normative/official representations of development against an inherently messy and unpredictable political process.

\section{NOTES}

I acknowledge the support of the UK Department for International Development, which hired me to undertake the various consultancies on which this paper is based. However, DFID support for my fieldwork should not be construed in any way as support for the arguments advanced in this paper. The assistance of David Nyamwaya and Irungu Horton is also gratefully acknowledged. My thanks to the $J A R$ reviewers, who provided many helpful suggestions to improve the paper.

1. The following acronyms are used in this paper: AAK (Action-Aid Kenya); CBOs (community-based organizations); DANIDA (Danish International Development Agency); DFID (United Kingdom Department for International Development); DFI (Direct Funding Initiative, funded by DFID); EGG (Economic Governance Group); DFRD (District Focus for Rural Development); INGO (International Non-Governmental Organization); KANU (Kenyan African National Union); NCCK (National Christian Council of Kenya); NGOs (Non-Governmental Organizations); OECD (Organization for Economic Cooperation and Development); PPI (Productive Physical Infrastructure); PRA (Participatory Rural Appraisal); PRSPs (Poverty Reduction Strategy Programs); SWAPs (Sector-Wide Approaches); SIDA (Swedish International Development Agency); USAID (United States Agency for International Development).

2. See the essays in World Development 15 (1987 supplement) and Drabek's summary of the key arguments (1987).

3. On the nature of civil society in Africa see Azarya (1994) and Callaghy (1994); see Campbell (2001) for a discussion of civil society and NGOs in Ethiopia.

4. A significant contributor to this strand of research originated from organizations which promoted better NGO management, planning, and evaluation via specialized training programs, such as INTRAC <http://www.intrac.org/>.

5. See Cooke and Kothari 2001; Botchway 2001. The principal exception has been the work of David Mosse (2001, 2005a, 2005b).

6. In urban areas more than 16,000 individuals were forced out by the police and bulldozers (Mungano wa Wanavijiji 1997).

7. The objectives of British policy in the early 1990s was to promote economic liberalization, enhance productive capacity, and encourage good government (see United Kingdom 1993). While the 1997 White Paper argued the case for a human-rights perspective in development, it continued to promote neoliberal policy reform (UK 1997).

8. Information on bilateral programs comes from the OECD $<\mathrm{http}: / /$ www.oecd. org/>.

9. Data come from interviews and documentation with UK DFID, USAID, the Royal Netherlands Embassy, DANIDA, SIDA, Canadian International Development Agency, the World Bank, the British Council, and the Ford Foundation.

10. The level of assistance varied tremendously: USAID channeled about $30 \%$ of its aid via American NGOs, The Netherlands channeled $10 \%$ of its aid through NGOs, and $13 \%$ of Danish aid went to NGOs. Data from OECD evaluations of bilateral programs.

11. For instance, the American embassy has been critical of the Kenyan government and has, from the late 1980s, funded NGOs as a means of bypassing the Kenyan government 
to pursue its own policy objectives (Hearn 2002).

12. Cooperation began to occur with the development of Sector-Wide Approaches (SWAPS) and the use of Poverty Reduction Strategy Programs (PRSPs), which provided a shared modality for pushing policy objectives and reforms in Kenya and elsewhere in Africa (Norton and Bird 1998; Bretton Woods Project 2003).

13. However, successful entrepreneurs tended to hire family members and not the unskilled or unemployed.

14. Interview with Mr. Solomon Mwangi, Appropriate Technologies for Enterprise Creation, 3 February 1994.

15. Interview with Ms. Karen Twining, director, Oxfam UK, 24 January 1994.

16. Their views were reflected in my report to the World Bank but were cut from the final report.

17. Mr. M. Mallalieu, Kenya Program Manager (DFID) and First Secretary of the High Commission, interviewed 26 June 1998.

18. Information, and the following quote, from an interview with Mr. N. Braakhuis, Counselor, Royal Netherlands Embassy, 7 July 1998.

19. "Capacity-building" has multiple meanings and may be delivered via quite different modalities. The extent to which capacity building actually enhances program delivery and organizational development is intensely debated.

20. The absence of a long-term and/or mutually agreed commitment to support NGOs makes it clear that DFID's support was narrowly defined to suit its own interests rather than the needs of a diverse and poorly organized sector.

21. Information comes from interviews with Ms. Jane Weru of Kituo cha Sharia (6 July 1998) and Ms. Helena Kithinji, an independent consultant/researcher (29 June 1998).

22. Interview with Mr. D. Weller, USAID (3 July 1998).

\section{REFERENCES}

Abrahamsen, R. 1997. The victory of popular forces or passive revolution? A neo-Granscian perspective on democratization. Journal of Modern African Studies 35:128-52.

Action-Aid Kenya (AAK). 1993. Country strategy paper, 1993-1997. Nairobi.

Azarya, V. 1994. "Civil society and disengagement in Africa," in Civil society and the state. Edited by J. Harbeson et al., pp. 83-100. Boulder, CO: Lynne Rienner.

Botchway, K. 2001. Paradoxes of empowerment: Reflections on a case study from northern Ghana. World Development 29:135-53.

Bratton, M. 1989. The politics of government-NGO relations in Africa. World Development 17:569-87.

Bretton Woods Project. 2003. Poverty Reduction Strategy Papers (PRSPs): A rough guide. London. Available online at $<\mathrm{http}$ ://www.brettonwoodsproject.org/>.

Callaghy, T. 1994. "Civil society, democracy and economic change in Africa: A dissenting opinion about resurgent societies," in Civil society and the state. Edited by J. Harbeson et al., pp. 231-54. Boulder, CO: Lynne Rienner.

Campbell, J. 1994. Kenya poverty assessment: Institutional and NGO analysis. Report on Kenya NGOs and poverty alleviation. The World Bank and UK ODA. Swansea: Centre for Development Studies, University of Wales.

. 1999. Outputs to purpose review of the Aga Khan Foundation's Kwale Rural Support Program. Kwale District, Coast Province. Swansea: BDDEA and Centre for Development Studies, University of Wales.

2001. "Drawing a line between autonomy and governance: The state, civil society and NGOs in Ethiopia," in The charitable impulse: NGOs and development in East and 
NE Africa. Edited by O. Barrow and M. Jennings, pp. 149-65. Oxford: J. Currey.

Campbell. J., and. I. Horton. 1998. Assessment of the role of the civil society sector in contributing to the elimination of poverty in Kenya. Swansea: BDDEA and Centre for Development Studies, University of Wales.

Chaiken, M. 1990. "Participatory development and African women: A case study from western Kenya," in Social development and applied anthropology. Edited by M. Chaiken and A. Fleuret, pp. 84-98. Boulder, CO: Westview Press.

Chambers, R. 1994. The origins and practice of Participatory Rural Appraisal. World Development 22:953-69.

Cooke, B., and U. Kothari, eds. 2001. Participation: The new tyranny? London: Zed.

Cornwall, A., S. Musyoki, and G. Pratt. 2001. In search of a new impetus: Practitioners' reflections on PRA and participation in Kenya. IDS Working Paper 131. Brighton.

Drabek, A., ed. 1987. Development alternatives: The challenge for NGOs. World Development 15 . Supplement.

Escobar, A., and S. Alvarez, eds. 1995. Encountering development: The making and unmaking of the Third World. Boulder, CO: Westview.

Ferguson, J. 1990. The anti-politics machine: Development, de-politicisation, and bureaucratic power in Lesotho. Cambridge: Cambridge University Press.

Frontier Consulting. 1996. Understanding our rights: Review of the public legal education work of human rights NGOs in Kenya. London.

- 1998. Evaluation of the 1997 Kenyan General Election Domestic Monitoring Project for DANIDA, DFID, SIDA and Royal Netherlands Embassy. Cape Town.

Gould, J. 2006. "Timing, scale and style: Capacity as governmentality in Tanzania," in The aid effect. Edited by D. Mosse and D. Lewis, pp. 61-84. London: Pluto Press.

Hauser, E. 1999. Ugandan relations with Western donors in the 1990s: What impact on democratization? Journal of Modern African Studies 37:621-41.

Hearn, J. 2002. The "invisible" NGO: US evangelical missions in Kenya. Journal of Religion in Africa 32:32-60.

Holloway, R. 1998. Sharpening the focus: Documenting the capacity building work of the NGO Support Programme of ActionAid Kenya. Nairobi.

Holmquist, F. 1984. Self-help: The state and peasant leverage in Kenya. Africa 54(3):7291.

Hyden, G., J. Court, and K. Mease. 2003. Civil society and governance in 16 developing countries. ODI World Governance Survey Discussion Paper 4. London.

Kanyinga, K. 1993. "The socio-political context of the growth of NGOs in Kenya," in Social change and economic reform in Africa. Edited by P. Gibbon, pp. 53-77. Stockholm: International African Institute.

Kenya, Republic of. 1998. National Poverty Eradication Plan. Post-Technical Workshop draft. 25 June. Nairobi.

1999. National Poverty Eradication Plan, 1999-2015. Implementation Work Plan. July 1999 - December 2000. Nairobi: Office of the President.

Lyons, M. 1998. AMREF Turkana CBHC Project: End of Project review. Nairobi.

Maina, W., B. Wamalwa, H. Sutherlund, and D. Thalman. 1997. Civic Education Evaluation for USAID. Preliminary report and analysis of key findings. Nairobi: USAID.

Markowitz, L. 2001. Funding the field: Notes on the ethnography of NGOs. Human Organization 60:40-46.

Mercer, C. 2002. NGOs, civil society and democratization: A critical review of the literature. Progress in Development Studies 2:5-22.

Mosse, D. 2001. "People's knowledge, participation and patronage: Operations and representations in rural development," in Participation - The new tyranny? Edited by 
B. Cooke and U. Kothari, pp. 16-35. London: Zed.

- 2005a. Cultivating development: An ethnography of aid policy and practice. London: Pluto Press.

2005b. "Global governance and the ethnography of international aid," in The aid effect. Edited by D. Mosse and D. Lewis, pp. 1-36. London: Pluto Press.

Mosse, D., and D. Lewis, eds. 2006. Development brokers and translators: The ethnography of aid and agencies. Bloomfield, CT: Kumarian Press.

Mungano wa Wanavijiji. 1997. Nairobi (leaflet distributed by Oxfam-Kenya).

Muir, A., and P. Riak. 1998. ActionAid Kenya NGO capacity building project final review. Nairobi: UK DFID.

Mwaniki, N. 1986. Against all odds: The dilemma's of women's self-help groups in Mbeere, Kenya. Africa 56(2):210-28.

Norton, A., and B. Bird. 1998. Social development issues in sector-wide approaches. Social Development Division Working Paper 1. London: DFID.

Odhiambo, O., S. Holden, and C. Ackello-Ogutu. 1998. Oxfam Wajir Pastoral Development Project: Economic impact assessment. Nairobi: Resource Management and Policy Analysis Institute.

Olivier de Sardan, J-P. 2005. Anthropology and development: Understanding contemporary social change. London: Zed.

Oxfam. 1996. Wajir Pastoral Development Project: Mid-term review. Nairobi.

Patrick, D., H. Els, and F. Wanyama. 2005. The emergence of multilevel governance in Kenya. Working Paper 7. Leuven: Interdisciplinary Research Group on International Agreements and Development.

Porter, D., B. Allen, and G. Thompson. 1991. Development in practice: Paved with good intentions. London: Routledge.

Schall, N. 1998. District Focus for Rural Development "Blue Book." Social Policy Advisory Services SPAS - Kenya. Usingen, Germany: Deutsche Gesellschaft für Technische Zusammenarbeit (GTZ).

Scotland, P., and S. Fleming, with J. Campbell. 1999. Review of the Direct Funding Initiative (DFI) in Kenya. Nairobi: BDDEA.

Southall, R. 1999. Reforming the state? Kleptocracy and the political transition in Kenya. Review of African Political Economy 79:93-108.

Thom, G. 1997. NGO/CBO capacity building. Summary of lessons learned and guidelines for DFI and its partners in Kenya, Tanzania and Uganda. Mimeo. Nairobi: BDDEA.

Udvardy. M. 1990. "Bringing home development: The impetus of ideology for women's groups near the Kenyan coast," in Social change and applied anthropology. Edited by M. Chaiken and A. Fluerett, pp. 182-96. Boulder, CO: Westview.

. 1998. Theorizing past and present women's organizations in Kenya. World Development 26:1749-61.

United Nations Development Program (UNDP). 2003. Kenya Development Cooperation Report. Nairobi.

United Kingdom. 1993. Aide memoire for the "ODA Strategic Review of British Assistance for Health and Population Sector in Kenya." Nairobi: UK Overseas Development Agency.

- 1997. Eliminating world poverty: A challenge for the $21^{\text {st }}$ century. White Paper on International Development. Cmd paper 3789. London. <Accessible at http://www. dfid.gov.uk/pubs/files/whitepaper2000.pdf>

van Gastel, J. and M. Nuijten. 2006. "The genealogy of the 'good governance' and 'ownership' agenda at the Dutch Ministry of Development Cooperation," in The aid effect. Edited by D. Mosse and D. Lewis, pp. 85-105. London: Pluto Press. 